ADDIN, Volume 11, Number 2, August 2017

\title{
THE DEVELOPMENT OF THE INDONESIAN CRIMINAL CODE DERIVED FROM THE YUDICIAL PARDON VALUE IN ISLAMIC LAW
}

\section{Sri Endah Wahyuningsih}

Sultan Agung Islamic University Semarang, Central Java, Indonesia endah.w@unissula.ac.id

\section{Jawade Hafidz}

Sultan Agung Islamic University Semarang, Central Java, Indonesia hafidzjawade@gmail.com

\section{Abstract}

This paper aims to make efforts to develop the Criminal Code derived from the yudicial pardon value in Islamic law as a law that lives and thrives in society. The Criminal Code as the basis of criminal law enforcement is a legacy of the Dutch era which do not know peace to end up the case. It is not in accordance to Pancasila as the basis for legal development in Indonesia. Research method used socio legal and qualitative data analysis. The result of the research claims that Islamic law is a legal source in the development of the justice Criminal Code, forgiveness is possible in the jarimah-hudud and qisas-diyat in solving the criminal case. Implementation in the development of the Criminal Code needs to be added to the reason for the abolition of criminal prosecution if between the perpetrator and the victim is 
already forgiven, further, in the case of a crime with a slight loss the judge may decide to be forgiven even if the defendant is found guilty.

Keywords: Development, Criminal Code, Yudicial Pardon, Islamic Law.

\section{Abstrak}

PERKEMBANGAN CRIMINAL CODE INDONESIA YANG BERASAL DARI NILAI JUDICIAL PARDON DALAM HUKUM ISLAM. Tulisan ini bertujuan untuk melakukan upaya pembangunan KUHP bersumber dari nilai permaafan dalam bukum Islam sebagai hukum yang bidup dan berkembang dalam masyarakat. Sebab, KUHP sebagai dasar penegakan bukum pidana merupakan warisan zaman Belanda yang tidak mengenal perdamaian dan permaafan sebagai dasar untuk. menghentikan perkara. Hal tersebut tidak sesuai dengan kondisi Indonesia yang sudah merdeka yang mendasarkan pada Pancasila sebagai dasar pembangunan bukumnya. Metode pendekatan dengan socio legal research dan metode analisis data kualitatif. Hasil penelitian bahwa bukum Islam merupakan sumber bukum dalam pembangunan KUHP yang berkeadilan, permaafan dimungkinkan untuk.jarimabbudud dan qisas-diyat dalam menyelesaikan perkara pidana. Implementasi dalam pembangunan KUHP perlu ditambabkan bahwa alasan hapusnya kewenangan menuntut pidana jika antara pelaku dan korban sudab ada permaafan. Dalam hal tindak pidana dengan kerugian yang sedikit, hakim boleh memutuskan untuk. dimaafkan, sekalipun terdakwa terbukti bersalah.

Kata Kunci: Pembangunan, Hukum Pidana Material, Permaafan, Hukum Islam.

\section{A. Introduction}

Historically the Indonesian Criminal Code in Indonesia is Wetboek van Strafrecht voor Nederlandsch Indie, which came into force on 1 January 1918 including the legal family of The Romano Germanic Family (Civil Law System), 
against the backgrounds of individualistic and liberalistic social life values ${ }^{1}$, so that the legal principles contained are mirrored from their point of $v^{2} w^{2}$, as the opinion of Rene David and John E.C.Brierley states ${ }^{3}$ : Civil Law System has undergone the influence of Christian morality and, since the Renaissance, philosophical teachings have given prominence to individualism, liberalism and individual rights. Henceforth, at the least for certain purposes, this reconciliation enables us speak of one great family of western law". And Western political, legal and educational structures would bring about important and far reaching change, legally and otherwise. ${ }^{4}$

The Criminal Code which was born from the liberal legal system according to Satjipto Rahardjo focused on individual independence ${ }^{5}$. Causing the purpose of criminal law enforcement to obtain substantive justice is not materialized because it still implements laws and regulations which are not based on the values that grow and develop within the community itself. ${ }^{6}$

${ }^{1}$ Satjipto Rahardjo, "Hukum Kita Liberal (Apa yang Dapat Kita Lakukan)", Kompas, 3 Januari 2001.

${ }^{2}$ According to Satjipto Rahardjo, the principles of law are to guard and nourish the laws and sections or fields of the law. Paton calls it a means by which the law is alive, growing and developing, in Satjipto Rahardjo, Hukum dalam Jagat Ketertiban, (Jakarta: UKI Press, 2006), 128.

${ }^{3}$ Rene David and John E.C.Brierley, Major Legal Systems in the World Today: an Introduction to the Comparative Study of Law, (London: Stevens and Sons, 1978), 24.

${ }^{4}$ Sherman A. Jackson, "Jihad and The Modern World", The Journal of Islamic Law and Culture, Volume 7, Number 1, 2002, 4.

${ }^{5}$ Satjipto Rahardjo, Hukum dalam Jagat Ketertiban, 128.

${ }^{6}$ Esmi Warassih in her inauguration speech as Professor believes that the application of a legal system that is not derived or grown from the content of society is a problem, especially in countries that are changing because of a mismatch between the values that support the legal system of other countries with values shared by members of the community itself. Esmi Warassih, "Pemberdayaan Masyarakat dalam Mewujudkan Tujuan Hukum", Speech 
According to the Criminal Code if a person's actions fulfill the element of formulation of offense in the Act and the perpetrator is capable of responsibility then the perpetrator must be punished, even if peace has occurred. To overcome these problems, it is necessary to update the Criminal Code (KUHP) which is derived from the values of religious law. ${ }^{7}$

Indonesia is not a secular State ${ }^{8}$. So that Islamic Law has the potential to contribute to the reform of Indonesian criminal law. According to Ichtiyanto, ${ }^{9}$ in fact Islamic law is in national law. In his "Existence" theory he states that: (1) Islamic law is part of Indonesian national law; (2) Islamic law is independent in the sense that its strength and dignity is recognized by national law and given status as a national law; (3) Islamic law norms (religion) serve as a filter of materials and main elements of Indonesian national law.

Based on the description, conceptually and fundamentally it is possible to transform Islamic Law into the National Law System, but the transformation of norms, values, principles of Islamic laws ${ }^{10}$ into national law does not mean automatically but must pass through the Pancasila tester.

Inauguration of Professorship Associate Professor in Legal Science at Faculty of Law Diponegoro University Semarang, Central Java, Indonesia, 2001, 12.

${ }^{7}$ Barda Nawawi Arief, Beberapa Aspek Kebijakan, Penegakan, dan Pengembangan Hukum Pidana, (Bandung, Citra Aditya Bhakti, 1998), 117.

${ }^{8}$ Moh. Rosyid, "Konsep Demokrasi dalam Islam”, Jurnal Addin, Volume 9, Number 1, February 2015, 17.

${ }^{9}$ Ichtiyanto, Ensiklopedia Hukum Islam, Volume III, (Jakarta: Ichtiar Baru van Hoeve, 1997), 713.

${ }^{10}$ Sudarto, "Studi Hukum yang Menunjang Pembangunan", Masalabmasalah Hukum, No. 1, Januari/Februari 1975, 26; and Muladi, "Pembaharuan Hukum Pidana Materiil Indonesia”, Makalah, Seminar dan Kongres ASPEHUPIKI Bandung, 17 Maret 2008, 5. 
The problem statements in this paper are how do the role of Islamic law in the development of the national legal system? How do the model of deliberation, consensus and forgiveness in solving criminal cases according to Islamic law and its implementation in the development of the Indonesian Criminal Code?

\section{B. Discussion}

\section{The Role of Islamic Law in National Legal System Development}

The Indonesian nation is a nation born from "... blessing of Allah Almighty, ..."11, this recognition is formally poured in the highest document The Preamble of the 1945 Constitution of the Republic of Indonesia, based on the Supreme Belief which is also included in Article 29 Paragraph (1) Chapter XI (on Religion) of the 1945 Constitution of the Republic of Indonesia. ${ }^{12}$

For Indonesia, there is a close relationship between state and religion based on the God Supreme which is the first principle of Pancasila, thus the Indonesian nation has a noble legal device as the foundation of the life of the nation and the state of Pancasila and the 1945 Constitution of the Republic of Indonesia.

The consequence of having Pancasila as the foundation of the nation's philosophy means that in every life of the nation and state must make Pancasila a philosophical foundation that animates every step of development including development in the field of law. The importance of the study of values of religious wisdom as the elaboration of the values of Pancasila is also based on:

${ }^{11}$ UUD NRI 1945, (Jakarta: Sekretariat Jenderal Mahkamah Konstitusi Republik Indonesia, 2005), 3.

${ }^{12}$ Ibid., 9. 
a. Article 1 (1) UU No. 48/2009 on Judicial Authority states "Judicial Power is the power of an independent state to administer the judiciary to enforce law and justice based on Pancasila, for the implementation of the State of the Republic of Indonesia";

b. Article 2 (1) UU No. 48/2009 states that the Judiciary is conducted "For the sake of Justice based on Belief in the one and only God";

c. Article 2 (2) UU No. 48/2009 on Judicial Power states "State courts implement and enforce law and justice based on Pancasila";

d. Article 8 (3) UU No. 16/2004 on the Prosecutor's Office states "For the sake of justice and truth based on Belief in the Almighty, prosecutors prosecute with confidence based on valid evidence".

Those statements are certainly not just statements without meaning, but they contain meanings and hopes to be implemented in the process of legal development in Indonesia. Hassan Ko Nakate ${ }^{13}$, a Professor at Japan's Doshisha University, asserted that "there is no legal system in the world comparable to Islamic law, especially in terms of stability and predictability, the Islamic legal system formed around the eighth century until now the rules are still valid".

Philip K. Hitti argued that, "The syari'ah, according to the traditional view is exsternal, universal, perfect, lift for all men at all time in all places". ${ }^{14}$ Jajat Burhanuddin

${ }^{13}$ Hassan Ko Nakate, in Seminar Internasional Rekonstruksi Sistem Hukum Indonesia Berdasarkan Nilai Islam, Universitas Islam Sultan Agung Semarang, February 1, 2011.

${ }^{14}$ Philip K. Hitti, Islam a Way of Life, (Minneapolis: University of Minnesota Press, 1971), 42. See also in Sirajuddin, Legislasi Hukum Islam di Indonesia, (Bengkulu: Pustaka Pelajar, 2008), 67. 
also argues that Islamic law developed as a modern law in Asiadi from the beginning of the $20^{\text {th }}$ century. ${ }^{15}$

The law in the Islamic view is part of morality, not merely the rules let alone contrary to the moral essence. If Islamic morality teaches justice, then the rule that does not give justice is not law. Islamic law teaches the supremacy of values. Islamic law is the aggregate of values and norms that contain these values. ${ }^{16}$

Regarding the relationship between moral and law, Hazairin ${ }^{17}$ explained in his inaugural address as Professor of Customary Law and Islamic Law at the Faculty of Law, University of Indonesia, September 13, 1952 stated, "The Republic of Indonesia is a state which stands on the conviction that law and morality (moral) can not be separated. Law without morality (moral) is tyranny. Moral without law is anarchy and utopi that can lead to immorality. Only laws embraced by morality (morals) and rooted in morality or morality can establish humanity. The conviction of the compound between law and morals is emblazoned in the 1945 Constitution in Article 29 Paragraph (1) which mentions 'State based on the One Godhead'. This verse implies that the state, nation, and

${ }^{15}$ Jajat Burhanuddin, "Aspiring for Islamic Reform Sautheast Asian Request Fatwas for in al-Manar", Journal Islamic Law in Society, Koninklijke Brill NV, Leiden, 2005, 10.

${ }^{16}$ Islamic law controls the substance of law and controls the inventors of the law through tightening requirements for the mujtahid. Siti Qomariah, "Development of National Law Amid the Plurality of Laws (Transformation of Islamic Law in the National Legal System of the Republic of Indonesia)", Dissertation, Doctoral Program of Law Science Universitas Diponegoro Semarang, 2011, 132. As for ijtihad, are laws whose understanding requires rationalization and empirical experience. This jurisdiction is very broad and generally involves the laws of human interaction and the environment. Understanding the law can accept changes to be adapted to the actual situation without losing its Islamic identity.

${ }^{17}$ Hazairin, Demokrasi Pancasila, (Jakarta: Bina Aksara, 1985), 103-104. 
society obey the divine norms, which include legal norms and moral or moral norms. Therefore, in the State of the Republic of Indonesia there should be no law that is contrary to the divine norm and should not be allowed to be morally or morally contrary to a divine norm."

Another opinion was also expressed by Imam alGhazali $^{18}$. With the theory of Siyasah al-Akblaq states that "between the unwritten moral law and the written state law has an unbroken relationship between one another intertwined for the benefit of human beings. It is impossible to endure a state law that is not moral, just as it is impossible that the moral law is not supported by the state".

Furthermore, al-Ghazali ${ }^{19}$ through the books he wrote after reflecting on the condition of the people who failed in building the civilization deeply, came to the conclusion that the first to be resolved for the resurrection of the ummah (society) is a scientific problem.

Danah Zohar and Ian Marshall ${ }^{20}$, respectively from Harvard University and Oxford University in their book, Spiritual Intelligence, state the role of religion and morals in building civilization, are by introducing "spiritual thinking" that by using the approach of spiritual intelligence (spiritual quition). It will be obtained the most perfect intelligence

${ }^{18}$ Zainal Abidin Ahmad, Konsepsi Negara Bermoral Menurut Imam alGhazali, (Jakarta: Bulan Bintang, 1975), 162.

${ }^{19}$ Adian Husaini, Ketua Dewan Da'wah Islamiyah Indonesia, in http:/ / www.cidesonline.org/content/view/119/65/, downloaded at June 19, 2016.

${ }^{20}$ Spiritual Intelligence (SQ) is the latest scientific findings as stated first by Danah Zohar and Ian Marshal, respectively from Harvard University and Oxford University through a very comprehensive research. Danah Zohar and Ian Marshal, Spritual Intellegence: The Ultimate Intelligence, (London: Bloomsbury, 2000), in Ary Ginanjar Agustian, Rahasia Sukses Membangun Kecerdasan Emosi dan Spiritual ESQ Berdasarkan 6 Rukun Iman dan 5 Rukun Islam, (Jakarta: Arga, 2011), xxxiv. 
(ultimate intelligence), is done by stripping the lines of formalism (existing rule) and transcendental, so that will be obtained new ideas that approached ultimate truth.

The historian Arnold Toynbee also emphasized the role of religion in a civilization. Toynbee emphasizes the "dynamic role" aspect of religion and spirituality in the birth and destruction of one civilization. He concludes that many civilizations are destroyed (death) because of "suicide" and not because of collision with outside forces. In a thorough study of the awakening and destruction of civilization, Toynbee discovered that religion and spirituality play the role of "chrysalis" (cocoon), which is the forerunner to the growth of one civilization. Therefore the spiritual aspect plays a central role in maintaining the existence and destruction of a civilization. Civilizations that have lost the core of his spirituality, then it will experience a decline (civilizations that lost their spiritual core soon fell into decline). ${ }^{21}$

The importance of spiritual aspect is not only in the process of building human civilization but especially in the development of science, including the science of law. Based on the foundation above the development of jurisprudence, especially in Indonesia actually is to build a religious moral science (religious wisdom) or contain the moral values of God Almighty God or with the approach of religious wisdom, because according to Satjipto Rahardjo law is not only as rule of law, but also as the rule of morality. ${ }^{22}$

${ }^{21}$ Adian Husaini, Ketua Dewan Da'wah Islamiyah Indonesia, in http:/ / www.cidesonline.org/content/view/119/65/, downloaded at June 19, 2016.

${ }^{22}$ Satjipto Raharjo, Sisi-sisi Lain Hukum di Indonesia, 22-23. 
That view according to Sudjito ${ }^{23}$ is called the holistic paradigm, while Fritjof Capra calls it a "deep ecology" view (inner ecology). According to him spiritual or religious consciousness is referred to as ecological consciousness. The view of "deep ecology" is an approach that does not separate humans or anything from their natural environment. ${ }^{24}$

The study of religious law system especially against Islamic law is not something new. The dynamics of positive law in Muslim-majority countries have long used Islamic law which is their basic law. Since its inception in the midst of society to become state law and then tangent with other legal systems in the world, Islamic law has got its maturity as other legal systems that have developed in the world including in Indonesia.

\section{Deliberation and Forgiveness in Islamic Criminal Law}

Indeed, Islamic law highly upholds the dignity of human beings and the source of peace and compassion ${ }^{25}$ because the goal of the decline of Islam itself is to maintain the benefit for human life in order to uplift the dignity of humanity and in order to save human beings both life in the world and hereafter.

${ }^{23}$ The holistic paradigm is that the implementation of the law must be done through the integrity of understanding, cultivation and organization in achieving substantive justice and social justice based on the One Godhead to achieve the happiness of the world and akherat. The results of interviews with the author Prof. Dr. Sudjito, SH, M.Si., Professor of Faculty of Law Gadjah Mada University. See also in "Negara Hukum dalam Perspektif Pancasila", http:/ / www.ugm.ac.id/index.php?page=rilis\&artikel=2450, downloaded on 02/08/2016.

${ }^{24}$ Fritjof Capra, Jaring-jaring Kehidupan: Visi Baru Epistemologi dan Kehidupan, trans. Saut Pasaribu, (Yogyakarta: Fajar Pustaka Baru, 2001), 18.

${ }^{25}$ Muh. Khamdan, "Rethinking Deradikalisasi: Konstruksi Bina Damai Penanganan Terorisme", Jurnal Addin, Volume 9, Number 1, February 2015, 191. 
In Islamic law known as the principle of forgiveness to the perpetrators of criminal acts both to the budud crime contained syubat, qisas-diyat and takzir criminal acts. For budud crimes in general the forgiveness can be given as long as the case has not been reported to the authorities, and as long as the budud criminal act contains syubat, thus the forgiveness may be given by the judge or the victim.

In addition to the forgiveness of the criminal act of budud according to Islamic Law also applies to criminal acts which is the adami right. If a person commits a crime of murder and torture, the victim or his heirs may reciprocate in accordance with the act of the offender (not to exceed the limit). However, if the victim or his heir wishes, they are allowed to apologize to the offender. And if they forgive the perpetrator's acts, the victim or heirs are entitled to diyat in accordance with the provisions of the Shari'a or on the agreement of both.

The number of qisas/diyat which is forgiven has been explicitly determined in Islamic law, and that it is the right of the victim or his family and it is not the right of the state/ authority. In addition in having set a number of diyat, Islamic law also allows the summed sum agreed between the victim and the perpetrator, and even may give pardon without demanding diyat at all.

According to Islamic law if the victim forgives and demands a number of diyat to the perpetrator then if the offender is not from a capable family, then the judge has the right to ask the family of the perpetrator to pay a specified amount of diyat. Further, if diyat is still not enough, the diyat is taken from Baitul Mal, which then submitted to the victim or his family. This is according to Abdullah Kelib ${ }^{26}$ called the

${ }^{26}$ Interviewed and discussion result with Abdullah Kelib, at Sultan Agung Islamic University Semarang, June 28, 2016. 
limited jama'iyah accountability, but the preferred is to forgive without demanding diyat at all, and is a noble deed and is very liked by Allah swt. The forgiveness is permissible on all criminal offenses and takzir which is adami right, whereas the budud crime which is the right of Allah is not permissible.

Forgiveness can be applied to the perpetrators of criminal acts of theft which is a budud crime based on the traditions that indicate that the terms of property and conditions do not require the enactment of criminally cutting hands can even be forgiven at all. The hadiths are narrated from Rafi' bin Khudaij r.a., said, Rasulullah saw. said, "There is no hand cut in the theft of tsamr and katsar." 27

In another hadith, it is also narrated that the theft committed in a place where there is no guard can also be forgiven, as is the narration of Abu Dawud and Nasaiy from 'Amru bin Syuaib from his father from his grandfather narrated that there was a man from the tribe of Mazinah asking the Prophet about theft Dates still in the tree, narrated:

Rasulullah saw. was asked about the (theft) of dates still hanging. Then the Messenger of Allah replied, "Whoever takes with his mouth (eaten) without intending to hide it, then he is not subject to any sanctions. Whoever carries it, then he must return it twice (from the value of the fruit he stole) and (shouldered) in return (sanction). And whoever steals it after being kept in the warehouse, and the level is equivalent to a shield, then he must be cut off his hand." 28

${ }^{27}$ Ats-tsamr is the name for the date palms that still hang on the tree, while al-katsar is a stolen date palm in order for it to cook (mature) elsewhere. Al-katsar also means the date of the young dates and the bunches, or the dense bunches of dates. Abdurrahman al-Maliki and Ahmad ad-Da'ur, Sistem Sanksi dan Pembuktian dalam Islam, (Bogor: Pustaka Thariqul Islam Izzah, 1984), 94.

${ }^{28}$ Ibid., 88. 
The theft carried out from the door and the open space or the storage area is not punishable by hand, Imam Abu Dawud narrated from 'Amru bin Syu'aib from his father from his grandfather said:

I heard someone from the tribe of Mazinah asked the Messenger of Allah (saw) about a goat stolen from his pasture. Rasulullah saw. said, "In that case, replaced twice the price and be borne in return (dependent) for him. Whereas the stolen from his cage, then the thief is cut off his hand if its value is equivalent to a shield." 29

Likewise for theft that does not reach the nishab is $1 / 4$ dinar (1.0625 grams of gold), then the culprit is not subject to the hand-cut criminally but may be subject to takzir. As the hadith of 'A'ishah r.a. She said, "Rasulullah saw. cut thief's hand at theft of $1 / 4$ dinar or more." 30

Another narration also mentioned Rasulullah saw. said, "Cut off the hand at $1 / 4$ dinars and do not cut off thieve's hands for stealing less than that." 31

In connection with the theft crime of Hanafi Mahzab, suggests that if the owner of the stolen property wants his thief to be subjected to a punishment then he must complain to qadhi to punish the perpetrator. But if the owner of the goods forgives the perpetrator and give up his property then the punishment can not be dropped but still can be punished takeqir. ${ }^{32}$

Based on the above matters, according to Islamic law forgiveness against the perpetrators of criminal acts of theft can be given by judges (qadhi) or by the owner of the goods.

${ }^{29}$ Ibid., 87.

${ }^{30}$ Ibid., 84.

${ }^{31}$ Ibid.

${ }^{32}$ Abdurrahman, Shariah The Islamic Law: Tindak Pidana dalam Syariat Islam, (Jakarta: Rineka Cipta, 1992), 12. 
Qadhi may excuse the offender of theft if done against the still-hanging fruit, the theft is done for food, and the theft committed against the goods that are not stored properly.

According to Islamic law on the crime of qisas-diyat, forgiveness of the victim will affect the sanctions given to the perpetrator of the crime, the punishment qisas change into punishment or even can be freed from the punishment diyat. The basis of the right to grant yudicial pardons to the victim or guardian to the offender is: Word of Allah swt. in Q.S. alBaqarah [2]: 178. "Meaning: believer, it is required of you to be affiliated with regard to those who are slain; Free people with free men, slaves with servants, and women with women. So whoever receives a forgiveness from his brother, let (the forgiving) follow in a good way, and let (who is paid) to pay (the) to the one who gives pardon in a good way (also). That is a relief from your Lord and a mercy. Whoever exceeds the limit after that, then for him a very painful punishment."

In another verse, it is contained in Q.S. al-Ma'idah [5]: 45, Allah swt. says, "And We have appointed them in it (Taurat) that the soul (reciprocated) with the soul, eyes with eyes, nose with nose, ears with ears, teeth with teeth, and wounds and its kisas. Whoever releases his (right of qisas), then releases that right(s) to be a sinner for him. Whoever does not decide the case according to what Allah has revealed, then they are the ralim (doing something which is not right)."

Another basis is the hadith narrated from Annas bin Malik explaining, "As far as I know every case has been reported to the Messenger of Allah (saw.), then he always ordered to be forgiven." (Ahmad bin Hanbal). ${ }^{33}$

${ }^{33}$ In H.A. Djazuli, Fiqh Jinayah (Upaya Menanggulangi Kejahatan dalam Islam), (Jakarta: Raja Grafindo Persada, 1997), 151. 
Abu Dawud narrated a hadith that the Messenger of Allah (saw.), has said, "Deliberate killing (the culprit) requires qisas, unless the guardian of the murderer forgives him." ${ }^{\prime 34}$ The Hadith of Bukhari Muslim narrated that Rasulullah saw. has decided that the families of the murdered people have two choices: take a ransom or be put to death..$^{35}$

It is further explained that the Messenger of Allah (saw.) has decided on the person who is exposed to murder or persecution may choose among three options: to kill him, forgive him or take a ransom. Whosoever has made a choice then forgives and then kills him, then for him hell forever and ever. That is killing after forgiving him or taking a ransom and killing the wrong person. ${ }^{36}$

From the verses of the Qur'an and hadith above it can be seen that the execution of qisas punishment can change if the family of the victim to give forgiveness. So in this case concerned is obliged to give something good to the victim or the victim's family in a good way as diyat or compensation.

There is also a demand to avoid as far as possible from the law of slaughter as according to Aisha, the Prophet Muhammad saw. said which means, "To avoid the law of the murder of Muslims, wherever possible should be made. It can be better to be released from the punishment. A judge, who is wrong to forgive, will be better than wrongly imposing a death sentence." ${ }^{37}$

Based on the verses of the Qur'an and the Prophetic traditions mentioned above, it can be taken to understand

\footnotetext{
${ }^{34}$ Sayyid Sabiq, Fikih Sunnah, Jilid 10 (Bandung: Alma'arif, 1997), 30.

${ }^{35}$ Ibnu Qayyim al-Jauziyah, I'lamul Muwaqi'in: Panduan Hukum Islam, (Jakarta: Pustaka Azzam, 2000), 864.

${ }^{36}$ Ibid.

${ }^{37}$ In Muh. Kasim Bakri, Hukum Pidana dalam Islam, (Sala: Ramadhani, 1958), 121.
} 
that Islam allows vengeance in balance with that perpetrated by the perpetrator, but the victim/guardian is recommended to forgive and still be able to demand diyat on the culprit, but more the main is to forgive and simultaneously free at all from the payment of diyat instead of qisas. The virtue of forgiving is essentially the Qur'anic letter of Q.S. asy-Syu'ara' [42]: 40, "And the reward of a crime is a similar crime, then whoever forgives and does good is rewarded by Allah. He does not like those who do wrong."

This principle of forgiveness is a very noble principle, since reconciliation is recommended not only to perpetrators of crimes deemed lenient but also to offenders such as murder and ill-treatment. And in the next verse Allah swt. enjoins that man can but forgive others' guilt but also be patient. And for them are promised reward in the sight of Allah and such actions including things that are preferred and preferred by Allah swt.

The virtue of patience rather than reply to evil with the same reward is also the principle of Islam according to the guidance of the Qur'an Q.S. an-Nahl [16]: 126 as follows, "And if you give a reply, then repay with the same reply as the torment imposed upon you. But if you are patient, it is better for those who are patient."

However, if the victim wants to punish then the reply should not exceed the limit as in Q.S. al-Hajj [22]: 60, "Meaning: Thus, and whosoever recompensed with the persecution which he suffered and then he was persecuted (again), surely God would help him. Surely Allah is the Most Forgiving, the Forgiving."

Based on the verses above, it can be taken that the person who committed the crime the victim or his heirs should first try to forgive the perpetrators, as long as the culprit will be aware and repent for the forgiveness given 
to him. But if you want to punish the punishment imposed on the perpetrator must be balanced with the crime. And if he releases his/her forgiveness then the victim may demand compensation by not exceeding the limit.

\section{Implementation of Yudicial Pardon Principle in the Development of the Indonesia Criminal Code}

As it is known that in the Criminal Code (WvS) prevailing in Indonesia so far not formulated general guidance of punishment that regulates the judge's forgiveness. The formulation of the yudicial pardon/rechterlijk pardon principle in the criminal code is important because it is based on the principle of flexibility/ elasticity and modification of punishment sourced from the values of religious wisdom.

Based on the results of research in Islamic law, it is known as the principle of yudicial pardon of criminal acts both against the criminal act of budud contained syubat, qisasdiyat criminal acts and takzir. For budud crimes, in general, the pardon can be given as long as the case has not been reported to the authorities, and as long as the budud criminal act contains syubat, thus the forgiveness may be given by the judge or the victim.

In addition to the forgiveness of the budud crime according to Islamic Law also applies to criminal act which is the right of adami. If a person commits a crime of murder and torture, the victim or his heirs may reciprocate in accordance with the act of the offender (not to exceed the limit). However, if the victim or his heir wishes, they are allowed to apologize to the offender. And if they forgive the perpetrator's acts, the victim or heirs are entitled to diyat in accordance with the provisions of the Shari'a or on the agreement of both. 
The number of diyat in qisas/diyat crime has been explicitly determined in Islamic law, and that it is the right of the victim or his family and not the right of the state. In addition to having set a number of diyat, Islamic law also allows the summed sum agreed between the victim and the perpetrator, and even may give pardon without demanding diyat at all.

According to Islamic law, if the victim forgives and demands a number of diyat to the perpetrator then if the offender is not from a capable family, then the judge has the right to ask the family of the perpetrator to pay a specified amount of diyat. And if the diyat is still not enough or the amount is less then the shortage is taken from Baitul maal, which then submitted to the victim or his family. This is according to Abdullah $\mathrm{Kelib}^{38}$ called the limited jam'iyah accountability, but the preferred is to forgive without demanding diyat at all, and is a noble deed and is very liked by Allah swt. The forgiveness is permissible on all criminal offenses and takzir which are the right of adami, whereas the budud crime which is the right of Allah is not permissible.

The concept of forgiveness in the provisions of Islamic law is different from the principle of yudicial pardon/ rechterlijk pardon mentioned in Article 55 Paragraph (2) of the 2008 Criminal Code Concept, which reads, "The light of the act, the personal circumstances of the maker or the circumstances at the time of the deeds or the subsequent acts, not to impose criminal sanction or to impose measures with respect to justice and humanity."

Furthermore, in the Explanation of Article 55 Paragraph (2) of the Draft Law of the Criminal Code of 2014 stated, "The provision in this verse is known as the

${ }^{38}$ Interviewed and discussion result with Abdullah Kelib, at Sultan Agung Islamic University Semarang, June 28, 2016. 
rechterlijk pardon principle which authorizes the judge to forgive someone guilty of a minor (non-serious) crime. This forgiveness is included in the judge's verdict which must still be stated that the defendant is proven to commit the crime charged to him."

The equation of the rechterlijk pardon principle in the Concept of the Criminal Code with the forgiveness of the budud crime is that the judges may both forgive even the offender is proven guilty, but in Islamic law a crime of forgiveness of theft has been established, and for all criminal acts of budud may be forgiven for the duration of the case Submitted to the ruler.

The forgiveness in qisas/diyat according to Islamic law forgiveness is solely the right of the victim or his family (which is the right adami), while the judges are only offered to the litigants and then decide and implement the decision by agreement parties lit up earlier.

In addition to the above remission, according to Islamic law is allowed on all the criminal acts of qisas/diyat and takezir crime which includes the right adami such as: the crime of intentional killing, murder by accident, assault and criminal offenses takzir like attempted murder and persecution.

Thus, forgiveness is permitted not only to the perpetrators of criminal acts with very mild classification but also to be granted to perpetrators of crimes with severe classifications such as criminal offenses of persecution.

Based on the description above, yudicial pardon/ rechterlijk pardon principle should be allowed not only to the offender with very mild classification, but it is also possible given to the perpetrators of serious criminal offenses is limited only to criminal acts which constitute adami rights. 
Giving pardon to the perpetrator is given by considering the criminality guidance as mentioned in Article 55 Paragraph (1) of the Criminal Code Concept, namely:

a. Mistakes of the criminal offender;

b. Motive and purpose of committing a crime;

c. The inner attitude of the criminal offender;

d. Whether a crime is committed by a plan;

e. How to commit a crime;

f. Attitudes and actions of the producer after committing a crime;

g. Curriculum vitae and social and economic circumstances of the offender;

h. The criminal effect on the future of the offender;

i. The effect of a crime on the victim or the victim's family;

j. Forgiveness of the victim and/or his family; and/or

$\mathrm{k}$. Public view of the crime committed.

Important to note is based on the circumstances at the time of the act or that ensues, (e.g., the offender is willing to give money adequate compensation for a criminal offense committed) and by considering the willingness and remission of the victims or their families, because if there had been willingness and Forgiveness will be able to remove feelings of hostility and revenge from the victim, but still need to be considered the purpose of punishment.

Based on the description above, the construction draft of the Criminal Code in Chapter III of Punishment, Crime, and Action, Article 55 Paragraph (2), namely the provisions on the principle of rechterlijk pardon needs to be expanded to remove the sentence that mentions severity of the act, so full as follows, "Personal circumstances maker or The circumstances at which the acts are committed or which occur later, may serve as a basis for consideration not 
to impose criminal or to impose measures with respect to justice and humanity."

omparison of Formulation of Rechterlijk Pardon Principle in the Proposed Reconstruction of the Upcoming Criminal Code, "The personal circumstances of the criminals or circumstances at the time of an act or subsequent acts may be grounds for consideration not to impose a criminal or to impose an action with regard to justice and humanity."

The phrase "mild deeds" in Article 55 (2) of the Draft Criminal Code is proposed to be eliminated, in order to allow for crimes which are adami right (such as torture) to be forgiven as long as it is received from the victim or the victim's family.

With the omission of the phrase "the mild of the act" will provide flexibility for the judge to forgive the offender related to the rights of adami with the condition if there is willingness of the victim or his heir, however the judge may still provide additional criminal to the offender, sufficient loss for his actions. However, if the victim or his family does not want to forgive, the judge should not forgive the perpetrator.

The Criminal Code so far, the attention to the victims has not been adequate. Since the punishment orientation according to the Criminal Code is retaliation for deeds (daadstrafrecht). This is very different from Islamic law, which is very concerned about the victims and their heirs. In the case of Criminal Acts which is the right of adami, then the victim or his family becomes the decisive person about what sanction will be imposed on the offender. If the victim wishes then it is permissible to reciprocate with what is equal to the act of the perpetrator, but more important is to forgive the offender either by requesting him or her without asking him to do so. 
Therefore, the position of just as judge is only mediyator and executor of court decision.

According to Sofjan Sauri Siregar, ${ }^{39}$ the sanctions imposed in Islamic law aims to ensure the survival of the victim or the heirs left behind due to the murder or persecution perpetrated by the perpetrator. For example, murder or torture is committed against the head of the family who is responsible for earning a living for other family members, so other family members may be abandoned, or if the persecution causes disability in the body, it can interfere in earning a living. Therefore Islamic law dictates that for the victims or their heirs if they forgive the perpetrators of the crime, they are entitled to a sufficient amount of compensation to ensure the survival of the victim or his heirs.

In addition to establishing a number of indemnities, Islamic law also allows a certain amount of agreement on the perpetrators and victims or their heirs. Thus according to the abilities of the perpetrators and the sincerity of the victims, this shows the principle of flexibility/elasticity of punishment in Islamic law.

\section{Conclusion}

Conceptually and fundamentally possible the transformation of Islamic Law into the development of the National Law, but the transformation of Islamic law must pass through Pancasila test stone which is a national legal philosophy. In Islamic law known as the principle of forgiveness to the perpetrators of criminal acts both to the budud crime contained syubat, qisas-diyat and takzir crime. For budud crimes, in general, the pardon can be given as long as

${ }^{39}$ Interviewed and discussion result with Sofjan Sauri Siregar, Rotterdam, Belanda, October 5, 2009. 
the case has not been reported to the authorities, and as long as the budud crime contains syubat, the forgiveness may be given by the judge or the victim.

In addition to the forgiveness of the budud crime according to Islamic Law also applies to criminal act which is the right of adami. If a person commits a crime of murder and torture, the victim or his heirs may reciprocate in accordance with the act of the offender (not to exceed the limit). However, if the victim or his heir wishes, they are allowed to forgive to the offender. And if they forgive the perpetrator's acts, the victim or heirs are entitled to diyat in accordance with the provisions of the Shari'a or on the agreement of both. The implementation of the concept of remission in the Criminal Code is inserted in Article 55 Paragraph (2) Criminal Code draft, the provisions on the principle rechterlijk pardon needs to be expanded to remove the sentence that mentions severity of the act, so full as follows, "The personal circumstances of the criminals or circumstances at the time of an act or subsequent acts may be grounds for consideration not to impose a criminal or to impose an action with regard to justice and humanity." Furthermore, it is necessary to add the reason for the abolition of criminal sanction if there has been a peace between the perpetrator and the victim. 


\section{REFERENCES}

Abdurrahman. Shariah The Islamic Law: Tindak Pidana dalam

Syari'at Islam. Jakarta: Rineka Cipta, 1992.

Agustian, Ary Ginanjar. Rahasia Sukses Membangun Kecerdasan

Emosi dan Spiritual ESQ Berdasarkan 6 Rukun Iman dan 5 Rukun Islam. Jakarta: Arga, 2011.

Ahmad, Zainal Abidin. Konsepsi Negara Bermoral Menurut Imam al-Ghazali. Jakarta: Bulan Bintang, 1975.

Arief, Barda Nawawi. Beberapa Aspek Kebijakan, Penegakan, dan Pengembangan Hukum Pidana. Bandung: Citra Aditya Bhakti, 1998.

Bakri, Muh. Kasim. Hukum Pidana dalam Islam. Sala: Ramadhani, 1958.

Burhanuddin, Jajat. "Aspiring for Islamic Reform Sautheast Asian Request Fatwas for in al-Manar", Journal Heinonline Islamic Law in Society, Koninklijke Brill NV, Leiden, 2005.

Capra, Fritjof. Jaring-jaring Kehidupan Visi Baru Epistemologi dan Kehidupan. Yogyakarta: Fajar Pustaka Baru, 2001.

David and John E.C. Brierley, Major Legal Systems in the World Today: an Introduction to the Comparative Study of Law, London: Stevens and Sons, 1978.

Djazuli, H.A. Figh Jinayah (Upaya Menanggulangi Kejahatan dalam Islam). Jakarta: Raja Grafindo Persada, 1997.

Hazairin. Demokrasi Pancasila. Jakarta: Bina Aksara, 1985.

Hitti, Philip K. Islam: a Way of Life. Minneapolis: University of Minnesota Press, 1971.

Ichtiyanto. In Ensiklpopedia Hukum Islam, Volume III. Jakarta: Ichtiar Baru van Hoeve, 1997. 
Jackson, Sherman A. "Jihad and The Modern World", The Journal of Islamic Law and Culture, Volume 7, Number 1, 2002.

al-Jauziyah, Ibnu Qayyim. I'lamul Muwaqi'in: Panduan Hukum Islam. Jakarta: Pustaka Azzam, 2000.

Khamdan, Muh. "Rethinking Deradikalisasi: Konstruksi Bina Damai Penanganan Terorisme", Jurnal Addin, Volume 9, Number 1, February 2015.

Maliki, Abdurrahman and Ahmad ad-Da'ur. Sistem Sanksi dan Pembuktian dalam Islam. Bogor: Pustaka Thariqul Islam Izzah, 1984.

Muladi. "Pembaharuan Hukum Pidana Materiil Indonesia", Paper, in Seminar and Kongres ASPEHUPIKI Bandung, Maret 17, 2008.

Nakate, Hassan Ko. In Seminar Internasional Rekonstruksi Sistem Hukum Indonesia Berdasarkan Nilai Islam, Sultan Agung Islamic University Semarang, Februari 1, 2011.

Qomariah, Siti. "Pembangunan Hukum Nasional di Tengah Pluralitas Hukum (Transformasi Hukum Islam dalam Sistem Hukum Nasional Republik Indonesia)", Dissertasion, Diponegoro University Semarang, 2011.

Rahardjo, Satjipto. "Hukum Kita Liberal (Apa yang Dapat Kita Lakukan)”, Kompas, January 3, 2001. 2006. . Hukum dalam Jagat Ketertiban. Jakarta: UKI Press, . Sisi-sisi Lain Hukum di Indonesia. Jakarta: Kompas, 2006.

Rosyid, Moh. "Konsep Demokrasi dalam Islam”, Jurnal Addin, Volume 9, Number 1, February 2015.

Sabiq, Sayyid. Fikih Sunnah. Bandung: Alma’arif, 1997. 
Sirajuddin. Legislasi Hukum Islam di Indonesia. Bengkulu: Pustaka Pelajar, 2008.

Sudarto. "Studi Hukum yang Menunjang Pembangunan", Masalah-masalab Hukum, Number 1, Januari/Februari 1975.

Wahyuningsih, Sri Endah. Prinsip-prinsp Individualisasi Pidana dalam Hukum Islam dan Pembaharuan Hukum Pidana. Semarang: Badan Penerbit Universitas Diponegoro, 2013.

Warasih, Esmi. "Pemberdayaan Masyarakat dalam Mewujudkan Tujuan Hukum", Speech Inauguration of Professorship Associate Professor in Legal Science at Faculty of Law Diponegoro University Semarang, Central Java, Indonesia, 2001.

Zohar, Danah and Ian Marshal. The Ultimate Intellegience. London: Bloomsbury, 2000. 